\title{
Expansion of vegetated coastal ecosystems in the future Arctic
}

\author{
Dorte Krause-Jensen ${ }^{1,2 *}$ and Carlos M. Duarte ${ }^{3,4,5}$ \\ ${ }^{1}$ Arctic Research Centre, Bioscience, Aarhus University, Århus, Denmark \\ ${ }^{2}$ Department of Bioscience, Aarhus University, Silkeborg, Denmark \\ ${ }^{3}$ Department of Global Change Research, Instituto Mediterráneo de Estudios Avanzados, IMEDEA (CSIC-UIB), Esporles, Spain \\ ${ }^{4}$ The UWA Oceans Institute and School of Plant Biology, University of Western Australia, Crawley, WA, Australia \\ ${ }^{5}$ Faculty of Biosciences, Fisheries and Economics, University of Tromsø, Tromsø, Norway
}

\section{Edited by:}

Elvira S. Poloczanska,

Commonwealth Scientific and Industrial Research Organisation, Australia

\section{Reviewed by:}

Guillem Chust, AZTI-Tecnalia, Spain William Gerald Ambrose, Bates College, USA

Michael Timothy Burrows, Scottish

Association for Marine Science, UK

\section{*Correspondence}

Dorte Krause-Jensen, Department of Bioscience, Arhus University, Vejlsøvej 25, 8600 Silkeborg,

Denmark

e-mail:dkj@dmu.dk
Warming occurs particularly fast in the Arctic and exerts profound effects on arctic ecosystems. Sea ice-associated ecosystems are projected to decline but reduced arctic sea ice cover also increases the solar radiation reaching the coastal seafloors with the potential for expansion of vegetated habitats, i.e., kelp forests and seagrass meadows. These habitats support key ecosystem functions, some of which may mitigate effects of climate change. Therefore, the likely expansion of vegetated coastal habitats in the Arctic will generate new productive ecosystems, offer habitat for a number of invertebrate and vertebrate species, including provision of refugia for calcifiers from possible threats from ocean acidification, contribute to enhance $\mathrm{CO}_{2}$ sequestration and protect the shoreline from erosion. The development of models allowing quantitative forecasts of the future of vegetated arctic ecosystems requires that key hypotheses underlying such forecasts be tested. Here we propose a set of three key testable hypotheses along with a research agenda for testing them using a broad diversity of approaches, including analyses of paleo-records, space-for-time substitutions and experimental studies. The research agenda proposed would provide a solid underpinning to guide forecasts on the spread of marine macrophytes onto the Arctic with climate change and contribute to balance our understanding of climate change impacts on the arctic ecosystem through a focus on the role of engineering species. Anticipating these changes in ecosystem structure and function is key to develop managerial strategies to maximize these ecosystem services in a future warmer Arctic.

Keywords: climate change, warming, sea-ice, marine vegetation, seagrasses, macroalgae, Arctic, ecological function

\section{INTRODUCTION}

Ecosystems are in a state of flux, undergoing constant changes in response to shifting environmental conditions, as evidenced by long-term chronosequences of ecosystem change derived from paleoecological reconstructions (Buchaca et al., 2011; Roberts and Hamann, 2011; Stroemberg, 2011). However, current changes in the biosphere deviate from the "business as usual" dynamics of ecosystem status because of the introduction of a new driver, anthropogenic forcing, acting at the planetary scale (Crowley, 2000; Santer et al., 2013). For instance, the current increase in atmospheric greenhouse gasses and the associated warming of the globe occur at unprecedented rates (IPCC, 2007, 2014) and prompt major changes in ecosystems worldwide (Parmesan and Yohe, 2003; Chen et al., 2011; Poloczanska et al., 2013). Whereas, most reports and research to-date on the consequences of anthropogenic environmental change on ecosystems focus on the losses (Hoegh-Guldberg et al., 2007; Duarte et al., 2012a,b), little attention has been given to the gains of new communities and ecosystems filling the gaps of declining communities.
The current emphasis on losses of ecosystems and/or ecosystem components with climate change reflects the responsibility of human activity as the driver of these changes, and the consequent efforts to mitigate pressures potentially leading to disruptive changes in ecosystems and associated impacts on society. Such focus on avoiding disruptive change is, for instance, reflected in the declared objective of the UN Framework Climate Change Convention to "stabilize greenhouse gas concentrations in the atmosphere at a level that would prevent dangerous anthropogenic interference with the climate system" (http://www. cop19.gov.pl/unfccc), where dangerous anthropogenic inference includes abrupt changes to ecosystems (IPCC, 2014). Species extinctions under global change due to anthropogenic pressures are of particular concern (Bellard et al., 2012), because these represent terminal events and irreversible loss. However, for the most part, changes involve shifts in species ranges conducive to local declines or increases. For instance, most species are shifting their biogeographic ranges poleward at average rates of about 5-20 $\mathrm{km}$ per decade for terrestrial species (Parmesan and Yohe, 2003; Chen et al., 2011) and 50-70 km per decade for marine species 
(Helmuth et al., 2006; Poloczanska et al., 2013), so some species decline or disappear locally whereas others colonize new areas as their ranges expand. However, the research focus on those species, habitats, and ecosystems that decline locally has not been sufficiently balanced with research on the new species, habitats, and ecosystems that will define the biodiversity of the future ocean. An approach to improve the balance in our assessment of changes in marine ecosystems with global change may be to focus on ecosystem functions and the services to society they support instead of solely focusing on the losses or declines in species. Moreover, a proper assessment of the impacts of declines and losses is impossible without considering the effect of gains. For instance, declines of cod stocks in the Scotian Shelf have led to shrimp and crab fisheries exceeding by value that of the cod fishery it replaced (Frank et al., 2005) while poleward expansion of cod habitat into the Arctic with climate change has led to enhanced arctic cod fishery with warming (Kjesbu et al., 2014).

The Arctic Ocean, arguably the region of the globe already experiencing the most substantial climate change (Duarte et al., 2012a,b), is particularly suited to illustrate the argument above. As the Arctic warms at twice the global mean rate (IPCC, 2007), arctic ecosystems are expected to exhibit particularly fast changes (Duarte et al., 2012a,b; Grebmeier, 2012). Annual sea ice is decreasing in extent by, on average, between 3.5 and $4.1 \%$ per decade, along with a reduction in thickness (Vaughan et al., 2013). In the summer of 2012 historical records of both summer minimum sea ice extent (Parkinson and Comiso, 2013) and maximum area of the Greenland ice cap affected by surface melting (Nghiem et al., 2012) were reached. As a result, the period of ice-free waters has increased greatly, by as much as 90 days between 1972 and 2011 in some regions of the Arctic (Vaughan et al., 2013). As a consequence of ice melting on land, the Arctic Ocean is receiving increasing amounts of ice melt water, causing a rapid freshening of the Arctic Ocean (Dai et al., 2009; McPhee et al., 2009). Ice loss and an extended open water period are leading to significant coastal erosion problems, particularly acute along the Siberian and Beaufort coasts (Lantuit et al., 2012). Increased freshwater discharge also contributes, along with resuspension of eroded coastal sediments(Lantuit et al., 2012), to increase turbidity in the coastal zone, which has been forecasted to reduce light penetration and primary production along the Siberian shelf, receiving the discharge of some of the world's largest rivers (Slagstad et al., 2011). The Arctic Ocean is also considered to be in risk of ocean acidification (Bellerby et al., 2005; Fabry et al., 2009), as the saturation state of carbonate minerals is already very low, and a further increase in anthropogenic $\mathrm{CO}_{2}$ would lead to even lower saturation state levels (Yamamoto et al., 2012; AMAP, 2013; Vaughan et al., 2013). Lastly, an emerging issue is the depletion of the stratospheric ozone layer over the Arctic, with an ozone hole-as defined for Antarctica-observed for the first time in 2011 (Manney et al., 2011). Increased UV radiation could impact on organisms inhabiting shallow waters, as ice loss increases exposure to solar radiation (Garcia-Corral et al., 2014) but this effect remains to be evaluated for shallow coastal ecosystems.

Overall, increased pelagic primary production is forecasted across much of the Arctic Ocean, as a result of increased solar radiation reaching the water column as the sea ice retreats (Arrigo et al., 2008; Slagstad et al., 2011), although available models diverge in the sign and magnitude of the forecasted changes (Popova et al., 2012), which are also likely to show regional contrasts (e.g., Slagstad et al., 2011).

Reduced ice extent is also expected to trigger large impacts on the arctic marine ecosystem, particularly those associated with ice as habitat (Duarte et al., 2012a,b). Whereas much attention has been devoted to the threats to key species, such as Calanus copepods (Wassmann, 2011), or charismatic species, such as the polar bear (Renaud et al., 2008; Wassmann, 2011), with arctic climate change, very little attention has been given to ecological significance of new species entering the Arctic and the expansion of existing arctic species. For instance, the cod stock in the Barents Sea has reached a historical maximum partially due to expansion of their suitable habitat with climate change, with this increase in cod stock catalyzed further by a sound management program (Kjesbu et al., 2014). This example shows how forecasts of future key species, habitats, and ecosystems in the Arctic with climate change might inform management and policy strategies to maximize the delivery of ecosystem services to society in the face of climate change.

Here we contribute to balance our understanding of climate change impacts on the arctic ecosystem through a focus on the role of engineering species expanding their range poleward into the Arctic and the functions and ecosystem services they support. First, we discuss the potential poleward expansion of kelp forests and seagrass meadows with climate change. We then consider the functional properties of these expanding ecosystems and their implications for biodiversity conservation and the flow of ecosystem services to society in the future. We conclude by discussing the research questions that need be addressed to provide reliable forecasts on the expansion of these ecosystems and the managerial strategies to maximize the associated flow of ecosystem services in a future warmer Arctic.

\section{MACROPHYTE-DOMINATED ECOSYSTEMS IN A WARMER ARCTIC}

Marine macrophytes, including seagrass and macroalgae grow in coastal waters down to the depth receiving about $1 \%$ of the incident solar radiation (Gattuso et al., 2006), with the deepest record of kelp (Agarum clathratum and Saccharina sp.) in the Arctic region reaching down to $>60 \mathrm{~m}$ in Disko Bay, Greenland (Boertmann et al., 2013), records of foliose red algae to similar depths in Svalbard and slow-growing encrusted red algae to even larger depths (Wulff et al., 2009; Wiencke and Amsler, 2012). In addition to light availability, the presence of marine macrophytes is constrained by the availability of suitable habitat, soft sediments in the case of seagrasses, and rocky bottoms in the case of most macroalgae, both of which are available along the arctic coast. In the Arctic, ice scour represents an additional limiting factor, as icebergs and large ice blocks may strand in the shoreline smothering any macrophyte vegetation present. Many species of macroalgae have been reported for the Arctic (Wulff et al., 2009; Wiencke and Amsler, 2012), with a particularly important presence, in terms of biomass and cover, of kelps including species of Saccharina, Laminaria, and Alaria and intertidal brown algae such as Ascophyllum nodosum and Fucus spp. (Mann, 1973; Vetrov 
and Romankevich, 2010, pp. 83, 100, 123; Wiencke and Amsler, 2012; Jueterbock et al., 2013). Only one seagrass species, Zostera marina (eelgrass), has been reported in the Arctic, with a northern limit at $70^{\circ} \mathrm{N}$ in the Arctic coasts of Norway (Ostenfeld, 1927) and Russia (Jacobs, 1984) and also occurring in Alaska under sea ice (McRoy, 1969, 1970). Forecasts suggest, however, that Zostera noltii may also migrate to polar regions in a warmer future (Valle et al., 2014).

The Arctic has a huge coastal area potentially available for macrophyte colonization. The total length of the coastline affected by the presence of permafrost in the northern hemisphere, which does not encompass all of the arctic coastline, is $407,680 \mathrm{~km}$ and constitutes approximately $34 \%$ of the world's coastline (Lantuit et al., 2012), with Greenland alone encompassing $12 \%$ of the world's coastline. The extensive coastline is matched by extensive shallow shelves, with the continental shelf area representing about $52.9 \%$ of the total area of the Arctic Ocean (Jakobsson, 2002). Hence, the Arctic Ocean contains a vast potential habitat for marine macrophytes. However, much of this potential habitat is unlikely to be occupied at present because it is permanently covered by ice, impacted by ice scouring or because dense ice cover limits the duration of the growth period (Müller et al., 2009; Kortsch et al., 2012; Krause-Jensen et al., 2012).

Warming of the Arctic is now changing the conditions for marine macrophytes. Ice cover is becoming thinner, less extended, and more ephemeral across the Arctic Ocean (Rodrigues, 2009; Wang and Overland, 2009). Although marine macrophytes are able to grow under ice (McRoy, 1969), ice loss favors the growth of marine macrophytes in two ways, (1) by increasing the cumulative irradiance received on the sea floor, which determines the capacity of marine macrophytes to grow and complete their life cycle, and (2) by releasing the mechanical stress of ice scouring on the seafloor, allowing marine macrophytes to become established. A seasonal ice period confined to the arctic night period, as forecasted for the Arctic Ocean in the future (Wang and Overland, 2009), may, therefore, favor marine macrophytes. Whereas, reduced ice cover will lead to increased incoming solar radiation, its underwater penetration may be reduced in some regions of the coastal Arctic by either increased turbidity from sediment inputs and resuspension or increased algal blooms (see above), which may buffer in these regions, to variable extents, the increase in solar radiation available to benthic macrophytes.

Warming of the Arctic also favors marine macrophytes in two different ways. First it allows their poleward range expansion. Most habitat-forming macroalgae of the Arctic have a temperate origin, suggesting a potential for further northward expansion with warming for North Atlantic as well as North Pacific species (e.g., Dunton, 1992; Müller et al., 2009; Wulff et al., 2009; Wilce and Dunton, 2014). This applies to different macrophyte habitats, such as belts of intertidal wrack (e.g., Ascophyllum nodosum, Fucus sp.), subtidal kelps (e.g., Saccharina latissima) growing on rocky shores and eelgrass (Zostera marina) meadows on shallow soft seafloors (Figure 1). Colonization of new habitats during range expansion depends on dispersal and the presence of continuous coastlines providing continuity between temperate and polar zones. These abound in the Arctic, with the coastlines of all arctic nations providing continuity between boreal and arctic zones.

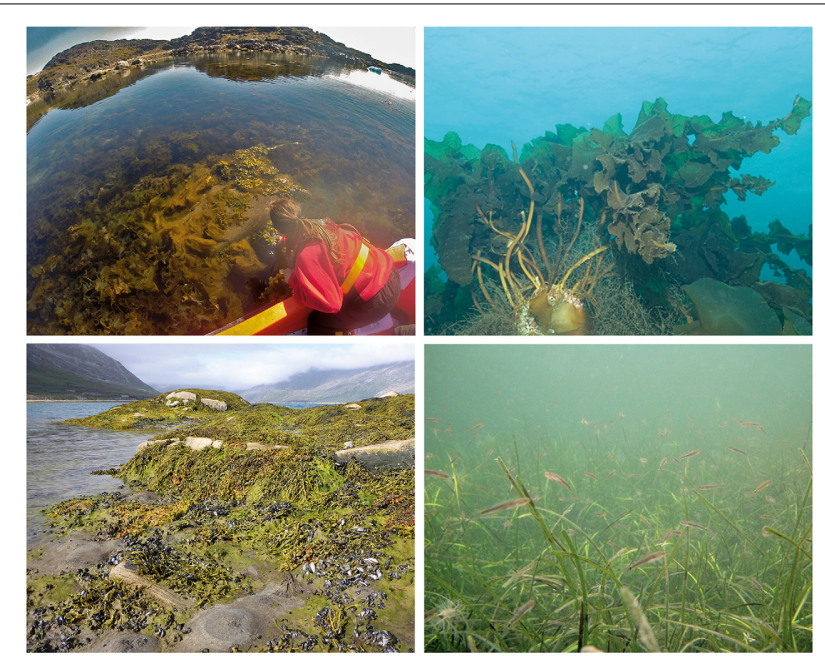

FIGURE 1 | Examples of vegetated coastal habitats in the Arctic. Upper left: Kelp-covered shallow cove dominated by Saccharina latissima, Disko Bay, Greenland (photo: Frida Lindwall). Upper right: Kelp habitat dominated by Saccharina latissimi, Norway's coast (photo: Stein Frederiksen). Lower left: Intertidal vegetation dominated by knotted wrack (Ascophyllum nodosum) and colonized by blue mussel (Mytilus edulis), Kobbe Fjord, Nuuk, Greenland (photo: Dorte Krause-Jensen). Lower right: Eelgrass ecosystem, Norway's coast (photo: Stein Frederiksen).

For instance, the coast of Greenland extends along $23^{\circ}$ latitude. The continuity of coastlines between the temperate and polar zones facilitates the poleward migration of temperate macrophyte species and is unique to the Arctic Ocean because the Southern Ocean acts as a barrier for dispersal of southern temperate species to Antarctica (Wulff et al., 2009; Jueterbock et al., 2013). Northern Hemisphere intertidal biota are already moving northwards at speeds of up to $50 \mathrm{~km}$ per decade (Helmuth et al., 2006; Hawkins et al., 2008; Weslawski et al., 2010), and there are reports of northward range extensions of kelps (Müller et al., 2009 and references therein; Wilce and Dunton, 2014), and new eelgrass meadows in Greenland (Olesen et al., 2014).

There are a few endemic species of arctic macroalgae, whose range is confined to the arctic region and whose future in a warmer Arctic could be of concern. However, the current northern boundary of arctic species such as Laminaria solidongula, as well as of cold-temperate species with arctic populations such as Saccharina latissima, matches the pack-ice border at ca. $80^{\circ} \mathrm{N}$, suggesting a poleward extension as the ice retreats northwards compensating a hypothetical poleward regression of the southern limit. Indeed, model forecasts for North Atlantic species predict that these kelps will expand their range poleward with arctic warming (Müller et al., 2009). Hence, there is at present no basis for concern on the possible extinction of any arctic macrophyte species with climate change.

In addition to favoring the poleward flux of species, arctic warming will likely affect their metabolic rates (Brown et al., 2004), increasing photosynthetic rates and growth and affecting their phenology, with an earlier initiation of growth and a longer season to complete their growth cycle (Kortsch et al., 2012; Krause-Jensen et al., 2012; Clausen et al., 2014; Olesen et al., 
2014). Moreover, future increases in atmospheric $\mathrm{CO}_{2}$, and airsea supply of $\mathrm{CO}_{2}$ may further propel macrophyte expansion in arctic waters. Marine macrophytes are often $\mathrm{CO}_{2}$-limited, because they have thick boundary layers that limit diffusional supply, thick tissues with high surface to volume ratio that limits uptake, and high volume density (i.e., g dry weight $\mathrm{m}^{-3}$ ) that, together with their characteristically high photosynthetic rates, lead to $\mathrm{CO}_{2}$ depletion within the canopy (Bowes, 1989; Sand-Jensen, 1989; Hurd, 2000). $\mathrm{CO}_{2}$ limitation of macrophyte growth may be particularly important in the Arctic because of characteristically low $\mathrm{pCO}_{2}$ in the spring, due to depletion by ice algae and pelagic microalgae and the ice pump (Rysgaard et al., 2009), and low water temperature conducive to low diffusion rates of $\mathrm{CO}_{2}$ in colder water as predicted by the increase in gas diffusion rate with $\mathrm{T}^{3 / 2}$ by the Chapman-Enskog theory (Chapman and Cowling, 1970).

Failure to complete the life cycle is one determinant of the northern limit of species. Temperature is a main driver of phenology and lower temperatures may, for instance, lead to delayed flowering of eelgrass at increasing latitude as this plant can initiate inflorescence at very cold temperature $\left(0.5-3^{\circ} \mathrm{C}\right)$, but requires about 1 month and $14-15^{\circ} \mathrm{C}$ for anthesis, and a further month for mature fruits to develop (Silberhorn et al., 1983). Mature fruits are developed already in April at the southern limit of this seagrass species, whereas in Nova Scotia at $44^{\circ} \mathrm{N}$ this happens only in July (Silberhorn et al., 1983). The Godthåbfjord system ( $64^{\circ} \mathrm{N}$, Nuuk, Greenland), is the northernmost location on the Greenland coast where eelgrass has been seen to develop mature fruits, but not until late August and only in warmer inner fjord branches (Olesen et al., 2014). Late August is close to the end of the growing season at $64^{\circ} \mathrm{N}$, suggesting that eelgrass may be unable to complete its life cycle further north at present even though it can sustain dense populations with biomass comparable to that developed further south (Olesen et al., 2014). Angiosperms have the capacity to complete their life cycle even in N. Greenland far beyond the Arctic Circle (Normand et al., 2013), so there is, in principle, no reason to believe that the photoperiod is an impediment for eelgrass, which has also been reported to cope well with temperatures near freezing point (McRoy, 1969), to do so as well. Flowering and seed production respond to warming in arctic land plants, which have been reported to advance and shorten the flowering period in recent warmer years with less snow cover (Høye et al., 2013). Likewise, a reduced ice cover, extending the length of the growing season, and warmer temperatures could allow the development of mature eelgrass seeds further north in the future than it is possible today (Figure 2). Closing the life cycle is not important only for the maintenance of the populations, but particularly critical to realize the potential poleward expansion of the northern distribution range of eelgrass, which depends on propagule supply.

Constraints on reproduction could also play a role in limiting the northern distribution range of macroalgal species such as Fucus vesiculosus and Acophyllum nodosum, which are currently distributed to $69^{\circ} \mathrm{N}$ on Greenland's west coast, although this is a

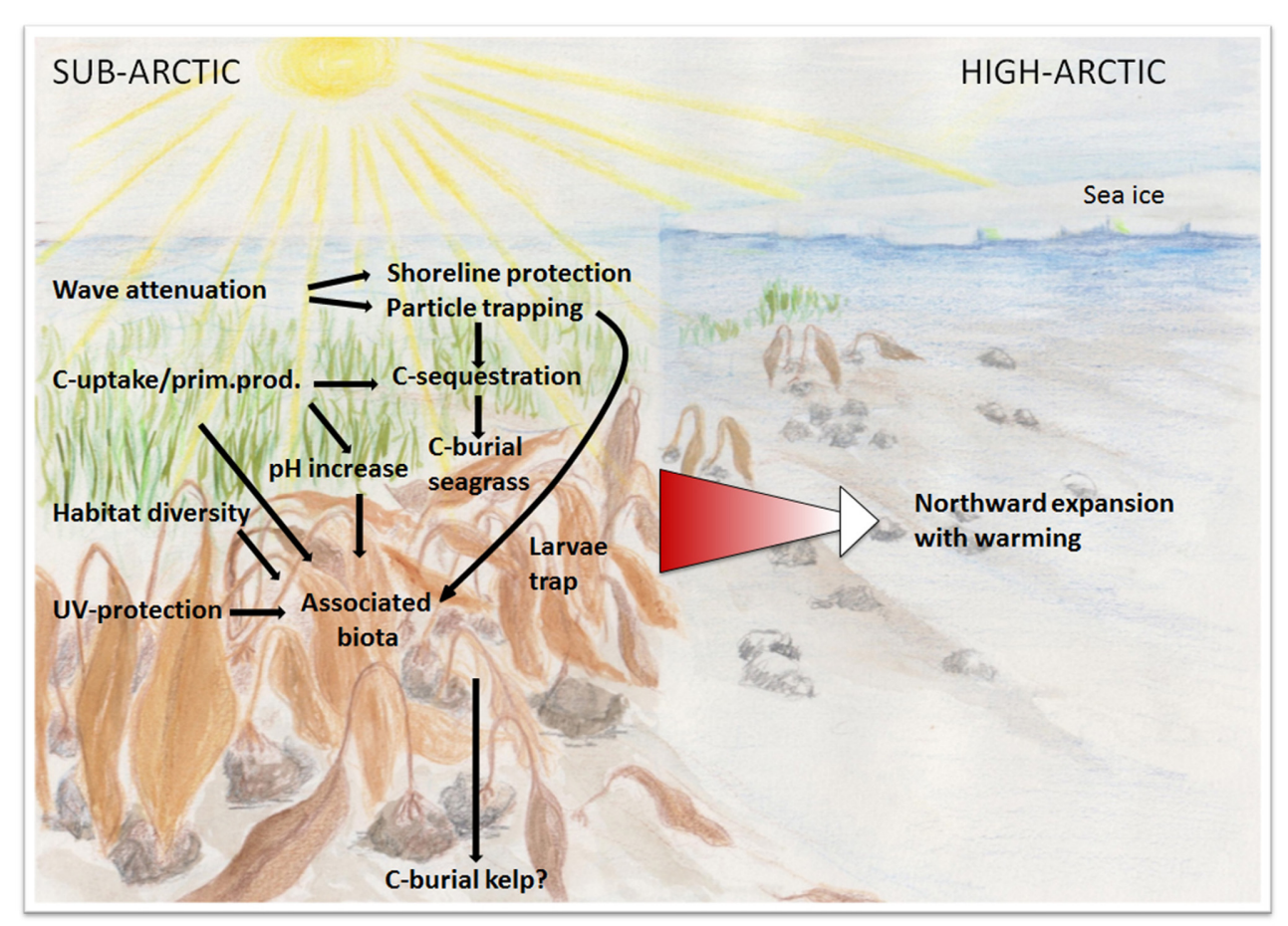

FIGURE 2 | Conceptual illustration of hypothesized northward expansion of vegetated ecosystems and associated ecosystem functions and societal services as warming reduces sea-ice cover and increases solar radiation to coastal arctic seafloors. Many of these services may act to mitigate effects of climate change: C-sequestration and burial, coastal protection via wave attenuation and sediment stabilization, high $\mathrm{pH}$ during intensive photosynthesis in the arctic summer. 
hypothesis that need be tested. In contrast, sporulation and germination of spores of kelps such as Saccharina latissima require low temperatures and short day lengths (Bartsch et al., 2008; Müller et al., 2009 and references therein) and Saccharina occurs and sporulates along the coast of Greenland to at least $78^{\circ} \mathrm{N}$ (Krause-Jensen et al., 2012) and on Svalbard at $80^{\circ} \mathrm{N}$ (Wiencke and Amsler, 2012). Hence, warming, increased light flux and $\mathrm{CO}_{2}$ in the future may affect the capacity of many arctic macrophytes to complete their life cycle, supporting the projected poleward expansion with climate change. We are not aware of any study that examines the combined role of these factors on the life cycles of arctic macrophytes. Available evidence suggest, however, that temperature may play a greater role for the expansion of eelgrass meadows than the length of the open-water period, determined by ice cover (Olesen et al., 2014), whereas the combined effect of warming and photoperiod may determine the northward expansion of Saccharina latissima (Müller et al., 2009).

\section{ECOSYSTEM FUNCTIONS AND SERVICES BY ARCTIC VEGETATED COASTAL HABITATS}

Marine macrophytes are recognized as effective ecosystem engineers (Gutiérrez et al., 2011), because they provide the foundations for the ecosystem by altering the physical, chemical, and biological conditions in the habitats they form. Via their engineering action kelps and seagrasses also support key ecosystem functions that have led these ecosystems to be ranked among the most valuable on the planet (Costanza et al., 1997). They stimulate biodiversity and play a nursery role by hugely increasing the colonizable area and providing habitat, shelter, and food for many organisms including some of commercial interest. A poleward spread of macroalgae and seagrass would provide arctic fauna, invertebrates, and fish with new or expanded habitats that may provide a nursery role. Indeed, macroalgae and seagrass are not expanding their ranges poleward alone, as many of their associated species are spreading poleward at comparable rates (Poloczanska et al., 2013). Hence, it is not just a habitat that spreads with the poleward range expansion of macroalgae and seagrass, but an entire ecosystem (Figure 2). For instance, kelps have been shown experimentally to offer refuge to juvenile cod in the presence of predators (Gotceitas et al., 1995). As cannibalism by arctic cod may be a bottleneck in population dynamics (Mehl, 1991), the presence of refugia for their juveniles may enhance population growth, consistent with indigenous knowledge of Greenlanders that cod captures are enhanced in areas near kelp forests (own observation). In addition, seagrass and kelp habitats have been shown to provide higher resource abundance for juvenile cod, which combined with the role of these habitats as refugia from predators leads to higher performance of the juveniles (Persson et al., 2012). While kelps are directly grazed by sea urchin (Steneck et al., 2002) and other herbivores, kelp detritus also contributes to magnify secondary production, and strong trophic links have been identified between kelps and a wide range of organisms of varied feeding strategies and trophic levels. Primary consumers in kelp beds in Alaska have been found to contain up to $>50 \%$ kelp-derived carbon (Dunton and Schell, 1987; Duggins et al., 1989). Hence, poleward spread of kelps and seagrass habitats may facilitate the poleward spread and population increase of a wide range of secondary producers including arctic cod.

Macrophyte canopies also dissipate wave energy and thereby stimulate sedimentation and improve water clarity. Vegetated habitats may even help mitigate climate change by supporting carbon burial in sediments, retaining large stocks of carbon in living biomass and protecting the shores from erosion through the dissipation of wave energy (Duarte et al., 2013a). Seagrass meadows and kelp forest rank among the most productive ecosystems on Earth and deliver substantial carbon inputs to the coastal food web while markedly influencing carbon and nutrient cycling of coastal ecosystems (Costanza et al., 1997). Because the tissues of seagrass and kelps typically have higher $\mathrm{C} / \mathrm{N}$ and $\mathrm{C} / \mathrm{P}$ ratios than those of phytoplankton, they are able to produce more organic matter and remove more $\mathrm{CO}_{2}$ per unit of limiting resources in the ecosystem (Duarte, 1992). Indeed, seagrass meadows and kelp forests tend to be highly autotrophic, exporting about 20-40\% of their net primary production (Duarte and Cebrián, 1996) and retaining carbon in sediments. The high capacity of seagrass to sequester and store carbon in sediments (Duarte et al., 2005; Fourqurean et al., 2012), provides a basis for strategies to mitigate climate change termed "blue carbon" strategies (Nellemann et al., 2009; Mcleod et al., 2011; Duarte et al., 2013a). The potential of arctic seagrass meadows to store carbon in their sediments has not yet been assessed, so their present and future contribution to carbon sequestration is yet to be quantified. Likewise, kelp forests grow on rocky bottoms, where carbon sequestration is not possible and are, therefore, believed not to contribute to long-term carbon sinks (Nellemann et al., 2009). Kelp-colonized boulder patches in the Alaskan Beaufort Sea have, thus, been identified as a non-depositional environment despite periodic accumulation of sediments on the seafloor (Dunton et al., 1982). However, as kelps export a large fraction of their production (Duarte and Cebrián, 1996), some of this may reach depositional areas and be sequestered in sediments. Arctic fjords have extensive depositional basins and steep slopes, providing an opportunity for kelp materials to be sequestered in adjacent sediments. This possibility, also to be evaluated, could be tested based on assessments of sediment carbon burial using stable carbon isotopes coupled with macroalgal-specific markers, such as specific lipids, carotenoids, and sterols markers of macroalgae. For instance, analyses of $\mathrm{C}$ and $\mathrm{H}$ stable isotopes in sterols in sediments allowed the reliable identification of contributions of brown and red algae to sediment organic carbon (Chikaraishi, 2006), lutein carotenoids were found to be useful markers of the contribution of advected seaweed to North Sea sediments (Abele-Oeschger, 1991) and specific lipids have been valuable in tracing seaweed carbon in coastal ecosystems (Xu and Hongsheng, 2007).

The autotrophic nature that supports the role of marine macrophytes as $\mathrm{CO}_{2}$ sinks also implies that they strongly affect the $\mathrm{pH}$ of coastal waters (Semesi et al., 2009; Duarte et al., 2013a; Hendriks et al., 2014). This confers these plants the potential to improve the conditions for calcifiers by increasing $\mathrm{pH}$ during their productive period, which is a particularly important function a future, more acidified ocean where lowered saturation state for carbonate minerals may compromise calcifying species (Orr et al., 2005). Dense macrophyte beds may, thus, upregulate 
$\mathrm{pH}$ by up to 1 unit during daytime (Middelboe and Hansen, 2007). Such increase in $\mathrm{pH}$ by macroalgal production is partially offset by community respiration during nighttime and periods of net decomposition and their net effect on $\mathrm{pH}$ depends on the temporal and spatial coupling of photosynthesis and community respiration as well as on burial of macroalgal detritus. Upregulation of $\mathrm{pH}$ is likely to be particularly pronounced in the arctic summer where macrophytes may remain productive, thereby maintaining elevated $\mathrm{pH}$ levels, during the $24 \mathrm{~h}$ of light of the day. Also, as mentioned above, a considerable part of the kelp production is likely exported away from the kelp forest (Duarte and Cebrián, 1996) and accumulated and decomposed elsewhere and typically later in the season outside the window for calcifier growth. Temporal and spatial uncoupling of kelp decomposition further enhances the role of the kelp habitat in raising $\mathrm{pH}$ during the growth season. Hence, submerged macrophyte vegetation may serve an additional climate change mitigation role in the arctic coastal ecosystems by raising $\mathrm{pH}$ levels during periods of intense photosynthesis (Hendriks et al., 2014), thereby providing local refuge for calcifying organisms (Semesi et al., 2009). However, this possibility is yet to be tested. The protective role of macrophytes also extends to providing shelter from elevated UVB radiation in shallow waters through the shading provided by their canopies.

Therefore, expansion of habitat-forming macrophytes along the massive coastline of the Arctic may have huge implications for the arctic coastal ecosystem that greatly exceed the direct effect of a warmer climate that initiated the expansion (Figure 2). Expansion of marine macrophytes in the Arctic may provide habitat for new species and refugia for existing ones (Dunton and Schell, 1987; Johnson et al., 2010; Wiencke and Amsler, 2012), and may help stabilize sediments along arctic coastlines where the lengthening of the open water season and the increasing open water area are likely to induce greater erosion in a warmer future (Lantuit et al., 2012). Quantitative models predicting the development of these ecosystems and their role in the Arctic are needed to support management strategies to catalyze their expansion and maximize their protective role and flow of ecosystem services to society.

\section{FORECASTING FUTURE COASTAL ECOSYSTEMS IN A WARMER ARCTIC: TOWARD A RESEARCH AGENDA}

Recent distribution models forecast the spread of marine macrophytes to the Arctic in response to temperature rise (Müller et al., 2009; Jueterbock et al., 2013) but there is a need to consider associated effects of reduced sea-ice cover and increased $\mathrm{CO}_{2}$ concentration on the performance of the macrophytes and predict the ecological consequences of the spread. Also the existing forecasts of macrophyte spread to the Arctic by Jueterbock et al. (2013) do not include the huge Greenland coastline. Extrapolation from models available elsewhere to the Arctic would yield unreliable results, for whereas the species involved may indeed spread onto the Arctic, the conditions they will find there will be outside the range currently encountered in the sub-Arctic, including for instance, extended arctic nights and arctic summers and other important elements, such as ice scour. Alternatively, the development of models on the performance of marine macrophytes in the ocean is precluded by the shifting conditions and communities, which will soon imply that the model would operate outside the domain of forcing factors for which it was created and validated.

We, therefore, propose that the analysis and forecasts on the spread of marine macrophytes onto the Arctic with climate change should start by defining a set of key testable hypotheses that, once evaluated, would provide solid underpinning to guide forecasts. To this end we submit the following key hypothesis:

1. Vegetated coastal habitats carry the potential for northward expansion in a future warmer Arctic as melting of sea ice increases the solar energy reaching seafloors along the extensive arctic coastline. The realization of the potential, however, depends on suitable dispersal vectors. A recent synthesis for marine ecosystems summarized changes in biota distribution, phenology, community composition, abundance, demography, and calcification that are generally consistent with expected impacts of climate change (Poloczanska et al., 2013). However, even though the review did include information on macroalgae and seagrasses it contained no such data from the Arctic, underlining a general scarcity of long timeseries from this region (Wassmann et al., 2011). Testing this hypothesis requires research on the environmental bottlenecks setting the northern limit of the species and comparing these against future conditions in the Arctic, as well as data mining for formal and anecdotal records of macrophyte spread in the Arctic and the development of paleo-reconstructions based on archives present in sedimentary environments, such as those offered by seagrass meadows (Duarte et al., 2013b).

Further, predicting the northward spread of marine vegetation in the future requires identification of the origin, dispersal corridors, and dispersal sources supporting the poleward migration of species ranges with climate change (Burrows et al., 2011, 2014) as well as vectors, such as current systems and animals that can disperse the propagules. For instance, the West Greenland Current flows northward and may facilitate transportation of propagules, while the prevailing southward currents along Greenland's east coast (Tang et al., 2004) may imply a larger dependence on biological vectors such as birds for northward dispersal. Eelgrass-grazing birds (e.g., brent geese, Clausen et al., 2002) may have played a role as vectors for the dispersal of eelgrass to Greenland's coasts. Human communities, contemporary, or historical (e.g., Norsemen and Middle Age populations) could also have have introduced the plants. While phenologies of eelgrass and brent geese do not suggest that the birds currently introduce eelgrass seeds from Europe or USA (Clausen et al., 2002), they may contribute to dispersal along Greenland's coast. Research on arctic terrestrial vegetation has shown that Greenland's terrestrial woody flora has a great potential for future expansion but is strongly dispersal limited, with a potentially important role of unintentional introductions (Normand et al., 2013).

2. Arctic coastal vegetation responds with increased growth and production to moderate warming, longer open-water periods, and increased $\mathrm{CO}_{2}$ concentrations, suggesting demographic prospects of extant populations in a warmer future. Long-term 
records on the performance (e.g., growth, production, population dynamics) of coastal vegetation are sparse or non-existing in the Arctic and, where existing, these will not suffice to test this hypothesis because the range of future conditions will exceed that captured in records. An alternative/supplementary approach, benefiting from the extensive latitudinal continuity of some of the arctic land masses, such as that of Greenland spanning along $23^{\circ}$ latitude, involves the substitution of space for time. Furthest north, the astronomical dark period in combination with prolonged sea ice cover (e.g., 9-10 months) only allows light to penetrate to the seafloor during part of the summer period, and water temperatures remain relatively constant and low throughout the year. But as the conditions currently encountered further south with longer open-water periods and higher water temperatures are projected to expand northwards, the performance of the vegetation in the south may provide hints on how the vegetation might perform under the future situations expected further north. Studies along geographical gradients have proven able to identify significant effects of climatic variables on the vegetation even though other factors such as nutrients, salinity, exposure, and grazing also play regulating roles (Krause-Jensen et al., 2012; Clausen et al., 2014; Olesen et al., 2014). Initial signs of positive responses of the vegetation to arctic warming and longer ice-free periods have also been reported (Weslawski et al., 2010; Kortsch et al., 2012; Krause-Jensen et al., 2012). Space-for-time substitutions along large spatial gradients have a limited ability to attribute the patterns to specific factors that may co-vary across these scales, such as light and temperature. However, regional heterogeneity in temperature and ice regimes within arctic coastal regions, where temperature may differ by as much as $5^{\circ} \mathrm{C}$ among internal vs. external coastal areas in fjord network systems sharing a similar latitudinal band (Olesen et al., 2014), allow for temperature and light effects to be disentangled. Likewise, light conditions may differ, as represented by, for instance, polynia vs. neighboring ice-covered sites. Hence, space-for-time substitutions are particularly effective when large scale latitudinal gradients are combined with studies across sites offering contrasting light and temperature regimes within latitudinal bands in a deliberate attempt to break the covariance between these putative drivers (Olesen et al., 2014). Space-for-time substitutions can help resolve and forecast the effects of warming and changing sea ice, but not that of increasing $\mathrm{CO}_{2}$. Increasing global levels of $\mathrm{CO}_{2}$ may further stimulate photosynthesis of marine plants (Beer and Koch, 1996; Thom, 1996), but predicting this will require experimental and field observations on responses of arctic macrophytes to increased $\mathrm{CO}_{2}$. Warming, increased light flux and increased $\mathrm{CO}_{2}$ levels in the future may affect the capacity of many arctic macrophytes to complete their life cycle, supporting the projected poleward expansion with climate change. Hence, testing this hypothesis will provide additional mechanistic understanding in support of models to forecast the poleward expansion of arctic marine plants in the future. We are not aware of any study that examines the combined role of all three factors on the life cycles of arctic macrophytes.
3. The key ecological functions macroalgae and seagrass support (e.g., stimulating biodiversity and element cycling, and mitigating climate change and its effects via carbon sequestration, elevating $p H$, and shoreline protection) are enhanced in the arctic summer because they depend on photosynthetic activity, which proceeds continuously during the arctic summer. Testing this hypothesis requires a combination of observations and controlled experiments on the dependence of these functions on photoperiod. Here again, space-for-time substitutions, through comparative analyses spanning from the sub-Arctic to the high-Arctic, may prove useful in testing the role of photoperiod in controlling the ecosystem functions supported by arctic marine plants.

\section{MANAGING FOR THE FUTURE ARCTIC VEGETATED COASTAL ECOSYSTEMS}

In areas of the Arctic where marine coastal vegetation has been largely absent due to the multiple bottlenecks (ice cover and ice scour) over much of the Holocene, there is probably limited awareness within traditional knowledge of the value of these habitats as sources of services to society. Successful management indeed relies on public awareness of those values, thereby calling for an effort of public outreach. Interviews to Greenlander communities indicate that traditional knowledge on kelps as food source played a role a couple of generations ago but has receded into the background along with the introduction of the import of vegetables grown further south made available through supermarkets (Krause-Jensen and Duarte, unpublished observation). Among the interviews only elderly women stated that they remembered eating seaweed in their childhood, particularly in periods when hunting was unsuccessful, with some still using kelps as an ingredient in fish soups. Traditional knowledge also to some extent connects the presence of the kelp with good opportunities for cod fishery. In the Disko Bay region we learned through our communication with locals that in some areas there was awareness that fjord systems with rich kelp forests supported very good cod-fishery and that drifting mats of kelps carried eggs and juveniles while in other areas we were told about good fishing places next to kelp forests but without any stated connection between these (Krause-Jensen and Duarte, unpublished observation). This type of information is supported by records in the literature of the importance of kelp in providing food and refugia for juvenile cod from predation and cannibalism (Gotceitas et al., 1995). Increasingly, traditional knowledge is being combined with Western scientific knowledge to develop sustainable adaptation strategies in the changing climate (Larsen et al., 2014). While there seems to have been some gap in the local interest in kelp over a couple of generations, our communication with the Qaasuitsup municipality in northwestern Greenland indeed indicated an incipient new awareness and interest in kelps. This municipality, which is very sparsely populated $(18,000$ inhabitants) but the most expanded $\left(660,000 \mathrm{~km}^{2}\right)$ municipality in the world, was looking into the possibilities for using seaweeds as a resource. Such increased awareness on the values of marine vegetation is a necessary first step toward the management of vegetated habitats in a future Arctic as societies would not find 
a rationale to manage a resource or habitat that they do not recognize as valuable.

The propagation of marine vegetation and their associated services, particularly those providing mitigation and adaptation to climate change, can be accelerated through management practices. These may include the identification of suitable sites where disturbances, such as impacts of water quality and physical impacts through anchoring and the establishment of coastal infrastructure to support expanding industry operations in the Arctic, should be avoided. The establishment of marine protected areas may further facilitate the spread and ensure protection of the habitats once established. Such considerations are important in the Arctic, which is becoming a hot spot for oil and mineral exploitation and shipping, along with the extensive coastal infrastructure that will be developed to support these activities. An important prerequisite for such management action is a monitoring program to identify the current distribution areas of kelps and follow their potential expansion into suitable habitats.

In summary, boreal and sub-Arctic species are forecasted to expand onto the Arctic Ocean with climate change. Among these, kelps and seagrasses will likely form new and expanded habitats supporting and enhancing ecosystem processes and services. The development of models allowing quantitative forecasts requires that key hypotheses underlying such forecasts be tested using a broad diversity of approaches, including observations, analyses of paleo-records, space-for-time substitutions and experimental studies. In addition to provide the underpinnings for model forecasts, this knowledge will be instrumental in deploying management strategies and policies to maximize the flow of ecosystem services to society. While loss of arctic species and habitats is indeed a matter of great concern, anticipating and managing the expanding ecosystems should also be a priority in managing a future, warmer Arctic for sustainability.

\section{ACKNOWLEDGMENTS}

The study was funded by the Danish Environmental Protection Agency within the Danish Cooperation for Environment in the Arctic (DANCEA) and is also a contribution to the Greenland Ecosystem Monitoring program (www.G-E-M.dk). We are thankful to Copenhagen University for providing excellent working facilities at the Arctic Station in Qeqertarsuaq, Disko Bay, Greenland, which inspired the study.

\section{REFERENCES}

Abele-Oeschger, D. (1991). Potential of some carotenoids in two recent sediments of Kiel Bight as biogenic indicators of phytodetritus. Mar. Ecol. Prog. Ser. Oldendorf 70, 83-92. doi: 10.3354/meps070083

AMAP. (2013). AMAP Assessment 2013: Arctic Ocean Acidification. Oslo: Arctic Monitoring and Assessment Programme (AMAP).

Arrigo, K. R., van Dijken, G. L., and Pabi, S. (2008). Impact of a shrinking Arctic ice cover on marine primary production. Geophys. Res. Lett. 35:L19606. doi: 10.1029/2008GL035028

Bartsch, I., Wiencke, C., Bischof, K., Buchholz, C. M., Buck, B. H., Eggert, A., et al. (2008). The genus Laminaria sensu lato: recent insight and development. Eur. J. Phycol. 43, 1-86. doi: 10.1080/09670260701711376

Beer, S., and Koch, E. (1996). Photosynthesis of marine macroalgae and seagrasses in globally changing $\mathrm{CO}_{2}$ environments. Mar. Ecol. Prog. Ser. 141, 199-204. doi: 10.3354/meps141199
Bellard, C., Bertelsmeier, C., Leadley, P., Thuiller, W., and Courchamp, F. (2012). Impacts of climate change on the future of biodiversity. Ecol. Lett. 15, 365-377. doi: 10.1111/j.1461-0248.2011.01736.x

Bellerby, R. G. J., Olsen, A., Furevik, T., and Anderson, L. G. (2005). "Response of the surface Ocean $\mathrm{CO}_{2}$ system in the Nordic Seas and Northern North Atlantic to climate change," in The Nordic Seas: An Integrated Perspective, Vol. 158, eds H. Drange, T. M. Dokken, T. Furevik, R. Gerdes, and W. Berger (Washington, DC: American Geophysical Union), 189-197. doi: 10.1029/158GM13

Boertmann, D., Mosbech, A., Schiedek, D., and Dünweber, M. (eds.). (2013). Disko West. A Strategic Environmental Impact Assessment of Hydrocarbon Activities. Scientific Report from DCE - Danish Centre for Environment and Energy No. 71, DCE - Danish Centre for Environment and Energy, Aarhus University.

Bowes, G. (1989). Photosynthesis and photorespiration. Aquat. Bot. 34, 1-299.

Brown, J. H., Gillooly, J. F., Allen, A. P., Savage, V. M., and West, G. B. (2004). Toward a metabolic theory of ecology. Ecology 85, 1771-1789. doi: 10.1890/039000

Buchaca, T., Skov, T., Amsinck, S. L., Gonçalves, V., Azevedo, J. M. N., Andersen, T. J., et al. (2011). Rapid ecological shift following piscivorous fish introduction to increasingly eutrophic and warmer lake furnas (Azores Archipelago, Portugal). A paleoecological approach. Ecosystems 14, 458-477. doi: 10.1007/s10021-0119423-0

Burrows, M. T., Schoeman, D. S., Buckley, L. B., Moore, P., Poloczanska, E. S., Brander, K. M., et al. (2011). The pace of shifting climate in marine and terrestrial ecosystems. Science 334, 652-655. doi: 10.1126/science.1210288

Burrows, M. T., Schoeman, D. S., Richardson, A. J., Molinos, J. G., Hoffmann, A., Buckley, L. B., et al. (2014). Geographical limits to species-range shifts are suggested by climate velocity. Nature 507, 492-495. doi: 10.1038/nature 12976

Chapman, S., and Cowling, T. G. (1970). The Mathematical Theory of Non-uniform Gases: an Account of the Kinetic Theory of Viscosity, Thermal Conduction and Diffusion in Gases. New York, NY: Cambridge University Press.

Chen, I. C., Hill, J. K., Ohlemuller, R., Roy, D. B., and Thomas, C. D. (2011). Rapid range shifts of species associated with high levels of climate warming. Science 333, 1024-1026. doi: 10.1126/science. 1206432

Chikaraishi, Y. (2006). Carbon and hydrogen isotopic composition of sterols in natural marine brown and red macroalgae and associated shellfish. Org. Geochem. 37, 428-436. doi: 10.1016/j.orggeochem.2005.12.006

Clausen, K. K., Krause-Jensen, D., Olesen, B., and Marba, N. (2014). Seasonality of eelgrass biomass across gradients in temperature and latitude. Mar. Ecol. Prog. Ser. 506, 71-85. doi: 10.3354/meps 10800

Clausen, P., Nolet, B. A., Fox, A. D., and Klaassen, M. (2002). Long-distance endozoochorous dispersal of submerged macrophyte seeds by migratory waterbirds in northern Europe-a critical review of possibilities and limitations. Acta Oecol. 23, 191-203. doi: 10.1016/S1146-609X(02)01150-5

Costanza, R., d'Arge, R., deGroot, R., Farber, S., Grasso, M., Hannon, B., et al. (1997). The value of the world's ecosystem services and natural capital. Nature 387, 253-260. doi: 10.1038/387253a0

Crowley, T. J. (2000). Causes of climate change over the past 1000 years. Science 289, 270-277. doi: 10.1126/science.289.5477.270

Dai, A., Qian, T., Trenberth, K. E., and Milliman, J. D. (2009). Changes in continental freshwater discharge from 1948 to 2004. J. Clim. 22, 2773-2792. doi: 10.1175/2008JCLI2592.1

Duarte, C. M. (1992). Nutrient concentration of aquatic plants. Patterns across specics. Limnol. Oceanogr. 37, 882-889. doi: 10.4319/lo.1992.37.4.0882

Duarte, C. M., Agusti, S., Wassmann, P., Arrieta, J. M., Alcaraz, M., Coello, A., et al. (2012b). Tipping elements in the Arctic marine ecosystem. Ambio 4, 44-55. doi: 10.1007/s13280-011-0224-7

Duarte, C. M., and Cebrián, J. (1996). The fate of marine autrotrophic production. Limnol. Oceanogr. 41, 1758-1766 doi: 10.4319/lo.1996.41.8.1758

Duarte, C. M., Kennedy, H., Marbà, N., and Hendriks, I. (2013b). Assessing the capacity of seagrass meadows for carbon burial: current limitations and future strategies. Ocean Coast Manage 83, 32-38. doi: 10.1016/j.ocecoaman. 2011.09.001

Duarte, C. M., Lenton, T. M., Wadhams, P., and Wassmann, P. (2012a). Abrupt climate change in the Arctic. Nat. Clim. Change 2, 60-62. doi: 10.1038/nclimate 1386

Duarte, C. M., Losada, I. J., Hendriks, I. E., Mazarrasa, I., and Marbà, N. (2013a). The role of coastal plant communities for climate change mitigation and adaptation. Nat. Clim. Change 3, 961-968. doi: 10.1038/nclimate1970 
Duarte, C. M., Middelburg, J., and Caraco, N. (2005). Major role of marine vegetation on the oceanic carbon cycle. Biogeosciences 2, 1-8. doi: 10.5194/bg-2-1-2005

Duggins, D. O., Simenstad, C. A., and Estes, J. A. (1989). Magnification of secondary production by kelp detritus in coastal marine ecosystems. Science 245, 170-173. doi: 10.1126/science.245.4914.170

Dunton, K. H. (1992). Arctic biogeography: the paradox of the marine benthic fauna and flora. Tree 7, 183-189. doi: 10.1016/0169-5347(92)90070-R

Dunton, K. H., Reimnitz, E., and Schonberg, S. (1982). An arctic kelp community in the Alaskan Beaufort Sea. Arctic 35, 465-484. doi: 10.14430/arctic2355

Dunton, K. H., and Schell, D. M. (1987). Dependence of consumers on macroalgal (Laminaria solidungula) carbon in an arctic kelp community: $\delta^{13} \mathrm{C}$ evidence. Mar. Biol. 93, 615-625. doi: 10.1007/BF00392799

Fabry, V. J., McClintock, J. B., Mathis, J. T., and Grebmeier, J. M. (2009). Ocean acidification at high latitudes: the bellweather. Oceanography 22, 160. doi: 10.5670/oceanog.2009.105

Fourqurean, J. W., Duarte, C. M., Kennedy, H., Marbà, N., Holmer, M., Mateo, M. A., et al. (2012). Seagrass ecosystems as a globally significant carbon stock. Nat. Geosci. 5, 505-509. doi: 10.1038/ngeo 1477

Frank, K. T., Petrie, B., Choi, J. S., and Leggett, W. C. (2005). Trophic cascades in a formerly cod-dominated ecosystem. Science 308, 1621-1623. doi: 10.1126/science.1113075

Garcia-Corral, L. S., Agustí, S., Regaudie-de-Gioux, A., Iuculano, F., Carrillo-deAlbornoz, P., Wassmann, P., et al. (2014). Ultraviolet radiation enhances Arctic net plankton community production. Geophys. Res. Lett. 41, 5960-5967. doi: 10.1002/2014GL060553

Gattuso, J.-P., Gentili, B., Duarte, C. M., Kleypas, J. A., Middelburg, J. J., and Antoine, D. (2006). Light availability in the coastal ocean: impact on the distribution of benthic photosynthetic organisms and their contribution to primary production. Biogeosciences 3, 489-513. doi: 10.5194/bg-3-489-2006

Gotceitas, V., Fraser, S., and Brown, J. A. (1995). Habitat use by juvenile Atlantic cod (Gadus morhua) in the presence of an actively foraging and non-foraging predator. Mar. Biol. 123, 421-430. doi: 10.1007/BF00349220

Grebmeier, J. M. (2012). Shifting patterns of life in the Pacific Arctic and sub-Arctic seas. Ann. Rev. Mar. Sci. 4, 63-78. doi: 10.1146/annurev-marine-120710-100926

Gutiérrez, J. L., Jones, C. G., Byers, J. E., Arkema, K. K., Berkenbusch, K., Commito, J. A., et al. (2011). Physical ecosystem engineers and the functioning of estuaries and coasts. Treat. Est. Coast. Sci. 7, 53-81. doi: 10.1016/B978-0-12-3747112.00705-1

Hawkins, S. J., Moore, P. J., Burrows, M. T., Poloczanska, E., Mieszkowska, N., Herbert, R. J. H., et al. (2008). Complex interactions in a rapidly changing world: responses of rocky shore communities to recent climate change. Clim. Res. 37, 123-133. doi: 10.3354/cr00768

Helmuth, B., Mieszkowska, N., Moore, P., and Hawkins, S. J. (2006). Living on the edge of two changing worlds: forecasting the responses of rocky intertidal ecosystems to climate change. Ann. Rev. Ecol. Sys. 37, 373-404. doi: 10.1146/annurev.ecolsys.37.091305.110149

Hendriks, I. E., Olsen, Y. S., Ramajo, L., Basso, L., Steckbauer, A., Moore, T. S., et al. (2014). Photosynthetic activity buffers ocean acidification in seagrass meadows. Biogeosciences 11, 333-346. doi: 10.5194/bg-11-333-2014

Hoegh-Guldberg, O., Mumby, P. J., Hooten, A. J., Steneck, R. S., Greenfield, P., Gomez, E., et al. (2007). Coral reefs under rapid climate change and ocean acidification. Science 318, 1737-1742. doi: 10.1126/science.1152509

Hurd, C. L. (2000). Water motion, marine macroalgal physiology, and production. J. Phycol. 36, 453-472. doi: 10.1046/j.1529-8817.2000.99139.x

Høye, T. T., Post, E., Schmidt, N. M., Trøjelsgaard, K., and Forchhammer, M. C. (2013). Shorter flowering seasons and declining abundance of flower visitors in a warmer Arctic. Nat. Clim. Change 3, 759-763. doi: 10.1038/ nclimate 1909

IPCC. (2007). Fourth Assessment Report: Climate Change 2007. Available online at: http://www.ipcc.ch/ipccreports/assessments-reports.htm

IPCC. (2014). Fifth Assessment Report. Climate Change 2014. Available online at: http://www.ipcc.ch/ipccreports/assessments-reports.htm

Jacobs, R. P. W. M. (1984). Biomass potential of eelgrass (Zostera marina L.). CRC Crit. Rev. Plant Sci. 2, 49-80. doi: 10.1080/07352688409382188

Jakobsson, M. (2002). Hypsometry and volume of the Arctic Ocean and its constituent seas. Geochem. Geophys. Geosyst. 3, 1-18. doi: 10.1029/2001GC000302

Johnson, S. W., Thedinga, J. F., Neff, A. D., Harris, P. M., Lindeberg, M. L., Maselko, J. M., et al. (2010). Fish assemblages in nearshore habitats of Prince William Sound, Alaska. Northwest Sci. 84, 266-280. doi: 10.3955/046.084.0306
Jueterbock, A., Tyberghein, L., Verbruggen, H., Coyer, J. A., Olsen, J. L., and Hoarau, G. (2013). Climate change impact on seaweed meadow distribution in the North Atlantic rocky intertidal. Ecol. Evol. 3, 1356-1373. doi: 10.1002/ece3.541

Kjesbu, O. S., Bogstad, B., Devine, J. A., Gjøsæter, H., Howell, D., Ingvaldsen, R. B., et al. (2014). Synergies between'climate and management for Atlantic cod fisheries at high latitudes. Proc. Natl. Acad. Sci. U.S.A. 111, 3478-3483. doi: 10.1073/pnas.1316342111

Kortsch, S., Primicerio, R., Beuchel, F., Renaud, P. E., Rodrigues, J., Lønne, O. J. et al. (2012). Climate-driven regime shifts in Arctic marine benthos. Proc. Natl. Acad. Sci. U.S.A. 109, 14052-14057. doi: 10.1073/pnas.1207509109

Krause-Jensen, D., Marbà, N., Olesen, B., Sejr, M. K., Christensen, P. B., Rodrigues, J., et al. (2012). Seasonal sea ice cover as principal driver of spatial and temporal variation in depth extension and annual production of kelp in Greenland. Glob. Change Biol. 18, 2981-2994. doi: 10.1111/j.1365-2486.2012.02765.x

Lantuit, H., Overduin, P. P., Couture, N., Wetterich, S., Aré, F., Atkinson, D. et al. (2012). The Arctic coastal dynamics database: a new classification scheme and statistics on Arctic permafrost coastlines. Est. Coasts 35, 383-400. doi: 10.1007/s12237-010-9362-6

Larsen, J. N., Anisimov, O. A., Constable, A., Hollowed, A., Maynard, N., Prestrud, P., et al. (2014). "Polar regions," in Climate Change 2014 Impacts, Adaptation and Vulnerability. Contribution of Working Group II to the Fifth Assessment Report of the Intergovernmental Panel on Climate Change (Cambridge; New York: Cambridge University Press).

Mann, K. H. (1973). Seaweeds: their productivity and strategy for growth. Science 182, 975-981. doi: 10.1126/science.182.4116.975

Manney, G. L., Santee, M. L., Rex, M., Livesey, N. J., Pitts, M. C., Veefkind, P., et al. (2011). Unprecedented Arctic ozone loss in 2011. Nature 478, 469-475. doi: 10.1038/nature10556

Mcleod, E., Chmura, G. L., Bouillon, S., Salm, R., Björk, M., Duarte, C. M., et al. (2011). A blueprint for blue carbon: towards an improved understanding of the role of vegetated coastal habitats in sequestering $\mathrm{CO}_{2}$. Front. Ecol. Environ. 9, 552-560. doi: 10.1890/110004

McPhee, M. G., Proshutinsky, A., Morison, J. H., Steele, M., and Alkire, M. B. (2009). Rapid change in freshwater content of the Arctic Ocean. Geophys. Res. Lett. 36:L10602. doi: 10.1029/2009GL037525

McRoy, C. P. (1969). Eelgrass under arctic winter ice. Nature 224, 818-819. doi: $10.1038 / 224818 \mathrm{a} 0$

McRoy, C. P. (1970). Standing stocks and other features of eelgrass (Zostera marina) populations on the coast of Alaska. J. Fish. Res. Board Can. 27, 1811-1821 doi: 10.1139/f70-199

Mehl, S. (1991). The Northeast Arctic cod stock's place in the Barents Sea ecosystem in the 1980s: an overview. Pol. Res. 10, 525-534. doi: 10.1111/j.17518369.1991.tb00670.x

Middelboe, A. L., and Hansen, P. L. (2007). High pH in shallow-water macroalgal habitats. Mar. Ecol. Prog. Ser. 338, 107-117. doi: 10.3354/meps338107

Müller, R., Laepple, T., Bartsch, I., and Wiencke, C. (2009). Impact of oceanic warming on the distribution of seaweeds in polar and cold-temperate waters. Bot. Mar. 52, 617-638. doi: 10.1515/BOT.2009.080

Nellemann, C., Corcoran, E., Duarte, C. M., Valdés, L., De Young, C., Fonseca, L., et al. (eds.). (2009). Blue Carbon. A Rapid Response Assessment. United Nations Environment Programme. Birkelant: GRID-Arendal. Available online at: www. grida.no

Nghiem, S. V., Hall, D. K., Mote, T. L., Tedesco, M., Albert, M. R., Keegan, K., et al. (2012). The extreme melt across the Greenland ice sheet in 2012. Geophys. Res. Lett. 39:L20502. doi: 10.1029/2012GL053611

Normand, S., Randin, C., Ohlemüller, R., Bay, C., Høye, T. T., Kjær, E. D., et al. (2013). A greener Greenland? Climatic potential and long-term constraints on future expansions of trees and shrubs. Philos. Trans. R. Soc. Lond. B Biol. Sci. 368:20120479. doi: 10.1098/rstb.2012.0479

Olesen, B., Krause-Jensen, D., Marbà, N., and Christensen, P. B. (2014). Eelgrass (Zostera marina L.) meadows in subarctic Greenland: dense meadows with slow biomass turnover. Mar. Ecol. Prog. Ser. (in press).

Orr, J. C., Fabry, V. J., Aumont, O., Bopp, L., Doney, S. C., Feely, R. A., et al. (2005). Anthropogenic ocean acidification over the twenty-first century and its impact on calcifying organisms. Nature 437, 681-686. doi: 10.1038/nature 04095

Ostenfeld, C. H. (1927). "Meeresgräser II - Marine Potamogetonaceae," in Die Pflanzenareale. Samlung Kartographischer Darstellungen von 
Verbreitungsbezirken der Lebenden und Fossilen Pflanzen-Familien, - Gattungen und -Arten, eds L. Diels and G. Samuelsson (Jena: Verlag von Gustav Fischer), 31-40.

Parkinson, C. L., and Comiso, J. C. (2013). On the 2012 record low Arctic sea ice cover: combined impact of preconditioning and an August storm. Geophys. Res. Lett. 40, 1356-1361. doi: 10.1002/grl.50349

Parmesan, C., and Yohe, G. (2003). A globally coherent fingerprint of climate change impacts across natural systems. Nature 421, 37-42. doi: 10.1038 /nature01286

Persson, A., Ljungberg, P., Andersson, M., Götzman, E., and Nilsson, P. A. (2012). Foraging performance of juvenile Atlantic cod Gadus morhua and profitability of coastal habitats. Mar. Ecol. Prog. Ser. 456, 245-253. doi: 10.3354/meps09705

Poloczanska, E. S., Brown, C. J., Sydeman, W. J., Kiessling, W., Schoeman, D. S., Moore, P. J., et al. (2013). Global imprint of climate change on marine life. Nat. Clim. Change 3, 919-925. doi: 10.1038/nclimate1958

Popova, E. E., Yool, A., Coward, A. C., Dupont, F., Deal, C., Elliott, S., et al. (2012). What controls primary production in the Arctic Ocean? Results from an intercomparison of five general circulation models with biogeochemistry. J. Geophys. Res. 117:C00D12. doi: 10.1029/2011JC007112

Renaud, P. E., Carroll, M. L., and Ambrose, W. G. Jr. (2008). "Effects of global warming on Arctic sea-floor communities and its consequences for higher trophic levels," in Impacts of Global Warming on Polar Ecosystems, ed C. M. Duarte (Madrid: Fundación BBVA), 139-175.

Roberts, D. R., and Hamann, A. (2011). Predicting potential climate change impacts with bioclimate envelope models: a palaeoecological perspective. Glob. Ecol. Biogeogr. 21, 121-133. doi: 10.1111/j.1466-8238.2011.00657.x

Rodrigues, J. (2009). The increase in the length of the ice-free season in the Arctic. Cold Reg. Sci. Technol. 59, 78-101. doi: 10.1016/j.coldregions.2009.05.006

Rysgaard, S., Bendtsen, J., Pedersen, L. T., Ramløv, H., and Glud, R. N. (2009). Increased $\mathrm{CO}_{2}$ uptake due to sea ice growth and decay in the Nordic Seas. J. Geophys. Res. 114:C09011. doi: 10.1029/2008JC005088

Santer, B. D., Painter, J. F., Bonfils, C., Mears, C. A., Solomon, S., Wigley, T. M. L., et al. (2013). Human and natural influences on the changing thermal structure of the atmosphere. Proc. Natl. Acad. Sci. U.S.A. 110, 17235-17240. doi: $10.1073 /$ pnas. 1305332110

Sand-Jensen, K. (1989). Environmental variables and their effect on photosynthesis of aquatic plant communities. Aquat. Bot. 34, 5-25. doi: 10.1016/03043770(89)90048-X

Semesi, S., Beer, S., and Björk, M. (2009). Seagrass photosynthesis controls rates of calcification and photosynthesis of calcareous macroalgae in a tropical seagrass meadow. Mar. Ecol. Prog. Ser. 382, 41-47. doi: 10.3354/meps07973

Silberhorn, G. M., Orth, R. J., and Moore, K. A. (1983). Anthesis and seed production in Zostera marina L. (eelgrass) from the Chesapeake Bay. Aquat. Bot. 15, 133-144. doi: 10.1016/0304-3770(83)90024-4

Slagstad, D., Ellingsen, I. H., and Wassmann, P. (2011). Evaluating primary and secondary production in an Arctic Ocean void of summer sea ice: an experimental simulation approach. Prog. Oceanogr. 90, 117-131. doi: 10.1016/j.pocean.2011.02.009

Steneck, R. S., Graham, M. H., Bourq, B. J., Corbett, D., and Erlandson, J. M. (2002). Kelp forest ecosystems, biodiversity, stability resilience and future. Environ. Conserv. 29, 436-459. doi: 10.1017/S0376892902000322

Stroemberg, C. A. E. (2011). Evolution of Grasses and Grassland Ecosystems. Annu. Rev. Earth Planet. Sci. 39, 517-544. doi: 10.1146/annurev-earth-040809-152402

Tang, C. C. L., Ross, C. K., Yao, T., Petrie, B., DeTracey, B. M., and Dunlap, E. (2004). The circulation, water masses and sea-ice of Baffin Bay. Prog. Oceanogr. 63, 183-228 doi: 10.1016/j.pocean.2004.09.005

Thom, R. M. (1996). $\mathrm{CO}_{2}$-Enrichment effects on eelgrass (Zostera marina L.) and bull kelp (Nereocystis luetkeana (mert.) P and R.). Water Air Soil Pollut. 88, 383-391. doi: 10.1007/BF00294113
Valle, M., Chust, G., del Campo, A., Wisz, M. S., Olsen, S. M., Garmendia, J. M., et al. (2014). Projecting future distribution of the seagrass Zostera noltii under global warming and sea level rise. Biol. Conserv. 170, 74-85. doi: 10.1016/j.biocon.2013.12.017

Vaughan, D. G., Comiso, J. C., Allison, I., Carrasco, J., Kaser, G., Kwok, R., et al. (2013). "Observations: Cryosphere," in Climate Change 2013: The Physical Science Basis. Contribution of Working Group I to the Fifth Assessment Report of the Intergovernmental Panel on Climate Change, eds T. F. Stocker, D. Qin, G.-K. Plattner, M. M. B. Tignor, S. K. Allen, J. Boschung, et al. (Cambridge: Cambridge University Press), 317-382.

Vetrov, A. A., and Romankevich, E. A. (2010). Carbon Cycle in the Russian Arctic Seas. Berlin; Heidelberg: Springer-Verlag.

Wang, M., and Overland, J. E. (2009). A sea ice-free summer Arctic within 30 years? Geophys. Res. Lett. 36:L07502. doi: 10.1029/2009GL037820

Wassmann, P. (2011). Arctic marine ecosystems in an era of rapid climate change. Prog. Oceanogr. 90, 1-17. doi: 10.1016/j.pocean.2011.02.002

Wassmann, P., Duarte, C. M., Agusti, S., and Sejr, M. K. (2011). Footprints of climate change in the Arctic marine ecosystem. Glob. Change Biol. 17, 1235-1249. doi: 10.1111/j.1365-2486.2010.02311.x

Weslawski, J. M., Wiktor, J. Jr., and Kotwicki, L. (2010). Increase in biodiversity in the Arctic rocky littoral, Sorkappland, Svalbard, after 20 years of climate warming. Mar. Biodivers. 40, 123-130. doi: 10.1007/s12526-0100038-z

Wiencke, C., and Amsler, C. D. (2012). "Seaweeds and their communities in polar regions," in Seaweed Biology, Ecological Studies, Vol. 219, Chapter 13, eds C. Wiencke and C. D. Amsler (Berlin; Heidelberg: Springer-Verlag), 510. doi: 10.1007/978-3-642-28451-9_13

Wilce, R. T., and Dunton, K. H. (2014). The Boulder Patch (North Alaska, Beaufort Sea) and its Benthic Algal Flora. Arctic 67, 43-56. doi: 10.14430/ $\operatorname{arctic} 4360$

Wulff, A., Iken, K., Quartino, M. L., Al-Handal, A., Wiencke, C., and Clayton, M. N. (2009). Biodiversity, biogeography and zonation of marine benthic micro- and macroalgae in the Arctic and Antactic. Bot. Mar. 52, 491-507. doi: 10.1515/BOT.2009.072

$\mathrm{Xu}$, Q., and Hongsheng, Y. (2007). Food sources of three bivalves living in two habitats of Jiaozhou Bay (Qingdao, China): indicated by lipid biomarkers and stable isotope analysis. J. Shellfish Res. 26, 561-567. doi: 10.2983/07308000(2007)26[561:FSOTBL]2.0.CO;2

Yamamoto, A., Kawamiya, M., Ishida, A., Yamanaka, Y., and Watanabe, S. (2012). Impact of rapid sea-ice reduction in the Arctic Ocean on the rate of ocean acidification. Biogeosciences 9, 2365-2375. doi: 10.5194/bg-92365-2012

Conflict of Interest Statement: The authors declare that the research was conducted in the absence of any commercial or financial relationships that could be construed as a potential conflict of interest.

Received: 23 September 2014; paper pending published: 17 October 2014; accepted: 28 November 2014; published online: 17 December 2014.

Citation: Krause-Jensen D and Duarte CM (2014) Expansion of vegetated coastal ecosystems in the future Arctic. Front. Mar. Sci. 1:77. doi: 10.3389/fmars.2014.00077

This article was submitted to Global Change and the Future Ocean, a section of the journal Frontiers in Marine Science.

Copyright (c) 2014 Krause-Jensen and Duarte. This is an open-access article distributed under the terms of the Creative Commons Attribution License (CC BY). The use, distribution or reproduction in other forums is permitted, provided the original author(s) or licensor are credited and that the original publication in this journal is cited, in accordance with accepted academic practice. No use, distribution or reproduction is permitted which does not comply with these terms. 